\title{
Association between Diabetes Mellitus and Leucocytic DNA Damage
}

\author{
Yim Tong Szeto and Ho Yan Yeung
}

\section{ABSTRACT}

\begin{abstract}
It has been suggested that diabetes is the disease associated with increased oxidative stress and might reflect with increased cellular DNA damage. To investigate the association between hyperglycaemic state and NDA damage of human white blood cells. The basal and UV-induced leucocytic DNA damages of 80 individuals, including 41 diabetic, 19 pre-diabetic patients and 20 normal subjects, were measured by comet assay. The HbA1c and fasting glucose levels were correlated to the DNA damage to detect the potential association. The leucocytic DNA damage was visualized under light microscope with Giemsa stain. The degree of DNA lesion was quantified by visual scoring. The diabetic patients showed the highest basal and UV induced DNA damage, while lowest scores were seen in healthy subjects. The DNA damages among diabetic, pre-diabetic patient and healthy subjects were significantly different from each other. There were significant positive correlations between the basal and UV-induced leucocytic DNA damages with HbA1c as well as fasting glucose levels. DNA damage as a marker of oxidative stress was seen in diabetic and pre-diabetic patients. The damage was positively correlated to the hyperglycaemic state of patient.
\end{abstract}

Keywords: comet assay, diabetes mellitus, DNA damage, glucose, $\mathrm{HbA}_{1 \mathrm{c}}$.
Published Online: May 14, 2021

ISSN: 2684-5199

DOI: $10.24018 /$ ejbio.2021.2.3.151

\section{Y. T. Szeto*}

Department of Chemistry, Hong Kong Baptist University, Hong Kong

(e-mail: ytszeto@alumni.vtc.edu.hk) H. Y. Yeung

Chan \& Hou Medical Laboratories Ltd, Hong Kong.

(e-mail: vincentyeungho@gmail.com)

*Corresponding Author

\section{INTRODUCTION}

Each human cell undergoes tens of thousands of DNA lesions every day due to the exposure to exogenous and endogenous agents which modified the structure of DNA. In response to the DNA damage, a series of DNA damage response (DDR) and DNA repair process are activated to restore genome integrity. If the lesions cannot be fully repaired or repaired incorrectly, the downstream genome replication, transcription and protein synthesis will be affected which attributable to the error in DNA sequence. The mutation of DNA sequence or wider-scale genome aberration will increase the chance of cancer.

Evidences suggest that hyperglycemia and hyperlipidemia contribute to the production of ROS and the formation of oxidation products such as 8-hydroxy-2'-deoxyguanosine (8OHdG) and lead to DNA strand break [1]. The excessive glucose in blood also reacts with plasma protein through Maillard reaction [2]. Advanced glycation end products (AGEs) are the products of protein glycation. Inflammatory pathway will be activated when AGEs bind to the AGE receptors and RONS are produced during inflammation [3]. It is believed that DNA damage contributes to mutagenesis, while DNA mutation is one of the causes of carcinogenesis. Animal study has shown downregulation of OGG1 protein expression in diabetic rat model [1]. OGG1 protein is DNA glycosylase enzyme that take part in the base excision repair pathway. The inhibition of DNA repair system may lead to the accumulation of DNA damage.

Approximately 463 million people in the world are suffering from diabetes and it is the sixth leading cause of death in the world [4]. Epidemiological studies provide strong evidence that diabetes is associated with increased risk of cancer development. It is reported that diabetes is one of the risk factors that contribute to all-site tumor in both male and female [5], [6]. Although strong linkage between DM and cancers have been observed, the underlying etiology and mechanism remain unclear and further investigation is required to develop cancer prevention strategy. In this study, the leucocytic DNA damage in healthy subjects, prediabetic and diabetic patients would be measured by comet assay. Differences in basal and UV-induced DNA damage among three groups would be investigated.

\section{METHODS}

Standard and type XI low gelling temperature agarose; ethylenediaminetetraacetic acid (EDTA); phosphate buffered saline (PBS); sodium chloride; Triton X-100 were from Sigma-Aldrich (St. Louis, MO, USA) were used. Tris (hydroxymethyl) aminomethane (Tris) was from Gibco (Carlsbad, CA, USA); and sodium hydroxide was from BDH (Poole, Dorset, UK). 
Eighty EDTA blood samples were investigated. Forty-one specimens were obtained from diabetes patients $\left(\mathrm{HbA}_{1 \mathrm{c}} \geq\right.$ $6.5 \%$ ) with different hyperglycaemic states, 19 specimens were obtained from pre-diabetic subjects (HbA1c 5.7 - 6.4\%) and 20 specimens were from healthy subjects $\left(\mathrm{HbA}_{1 \mathrm{c}}<\right.$ $6.4 \%$ ). Since age has been reported to associate positively with DNA damage, only subjects aged from 50 - 60 years old were included in the study [7]. Ethical approval was granted by the ethics committee of the Macao Society for the Study of Women's Health. Patients demographic information including age and sex, $\mathrm{HbA}_{1 \mathrm{c}}$ level and lipid profile were also retrieved for reference. All blood samples were stored at $20{ }^{\circ} \mathrm{C}$ before testing.

The leucocytic DNA damage was measured by comet assay. The protocol of the modified comet assay with the use of whole blood was adapted from previous study [8]. It has been shown that whole blood samples with or without freezing demonstrate no significant differences in DNA damage [9].

The microscopic slides were pre-coated with $1 \%$ agarose in PBS for subsequent gel adhesion. Sixteen $\mu \mathrm{L}$ of blood and $340 \mu \mathrm{L}$ of $1 \%$ low melting point agarose were added into $1.5 \mathrm{~mL}$ microtube and gently mixed. One hundred $\mu \mathrm{L}$ of mixture was then applied onto the slide immediately and covered by $22 \times 22 \mathrm{~mm}$ coverslip. Coverslip was removed from the gel after solidified at room temperature. Two gels from one sample were prepared, one would be subjected to UV treatment and the acted as control. UVB light irradiated on the slide for 2 minutes at $6 \mathrm{~cm}$ distance right before lysis.

The lysis solution (0.35 mL Triton X-100/ $3.5 \mathrm{~mL}$ DMSO/ $35 \mathrm{~mL}$ stock lysis solution, $2.5 \mathrm{M} \mathrm{NaCl}, 0.1 \mathrm{M}$ EDTA, $1 \mathrm{mM}$ Tris, $\mathrm{pH}$ 10) was mixed before used. The slides were transferred into staining jar containing lysis solution at $4^{\circ} \mathrm{C}$ and lysed for 1 hour. They were then immersed in cold electrophoresis solution after lysis solution drained. The gels underwent alkaline treatment for two changes of electrophoresis solution at $4{ }^{\circ} \mathrm{C}$ and 10 minutes per change. The slides were then placed on electrophoresis tank platform which was filled with cold electrophoresis solution. Initial current was set at $0.3 \mathrm{~A}$ and $25 \mathrm{~V}$ constant voltage applied for 30 minutes in cold room. Slides were transferred to staining jar with distilled water to remove electrophoresis solution afterwards. Three changes and each for 5 minutes per change before the slides were then air-dried at room temperature.

Five $\mathrm{mL}$ of stock Giemsa solution was added to $95 \mathrm{~mL}$ of PBS ( $\mathrm{pH}$ 7.2). The slides were stained for 30 minutes. They were then rinsed under tap water gently and air-dried. DNA damage was quantified by scoring 100 nuclei on each gel under microscope. DNA damage for each nucleus was classified from 0 (undamaged) to 4 (severe damaged with developed tail).

The differences between DNA damage (baseline and UV induced) among three group were tested by ANOVA followed by Bonferroni's multiple comparison test. $\mathrm{P}$ value less than 0.05 was regarded as statistically significant. Pearson correlation was used to determine the correlation between DNA damage and $\mathrm{HbA}_{1 \mathrm{c}}$ value. (Prism 5.0, GraphPad Software Inc., La Jolla, CA, USA).

\section{RESUlTS}

A total of 80 specimens were tested which included 41 diabetic, 19 pre-diabetic patients and 20 healthy subjects. The average age of the patients was $56.2 \pm 3.2$ years old. The mean $\mathrm{HbA}_{1 \mathrm{c}}$ level of these three groups were $7.4 \pm 0.9,6.0 \pm 0.3$ and $5.4 \pm 0.2 \%$, respectively. The patient demographics including age and sex, $\mathrm{HbA}_{1 \mathrm{c}}$, fasting glucose and lipid levels were shown in Table I.

TABLE I: DEMOGRAPHIC AND LABORATORY DATA OF DiABETIC, PREDiABETIC PATIENTS AND HEALTHY SUBJECTS

\begin{tabular}{|c|c|c|c|}
\hline Variables & $\begin{array}{l}\text { Diabetic } \\
\text { patients } \\
(\mathrm{n}=41)\end{array}$ & $\begin{array}{l}\text { Pre-diabetic } \\
\text { patients } \\
(n=19)\end{array}$ & $\begin{array}{l}\text { Healthy } \\
\text { subjects } \\
(n=20)\end{array}$ \\
\hline Age & $56.0 \pm 3.2$ & $56.5 \pm 2.9$ & $56.4 \pm 3.6$ \\
\hline $\operatorname{Sex}(M / F)$ & $28 / 13$ & $9 / 10$ & $11 / 9$ \\
\hline $\begin{array}{c}\text { Fasting blood } \\
\text { glucose }(\mathrm{mmol} / \mathrm{L})\end{array}$ & $6.7 \pm 1.2$ & $5.6 \pm 0.6$ & $5.1 \pm 0.5$ \\
\hline HbA1c $(\%)$ & $7.4 \pm 0.9$ & $6.0 \pm 0.3$ & $5.4 \pm 0.2$ \\
\hline Cholesterol (mmol/l) & $4.23 \pm 0.98$ & $4.40 \pm 1.06$ & $4.64 \pm 1.10$ \\
\hline $\begin{array}{l}\text { Triglycerides } \\
\text { (mmol/l) }\end{array}$ & $1.47 \pm 0.81$ & $1.24 \pm 0.71$ & $1.25 \pm 0.52$ \\
\hline $\begin{array}{l}\text { HDL cholesterol } \\
\qquad(\mathrm{mmol} / \mathrm{l})\end{array}$ & $1.23 \pm 0.29$ & $1.30 \pm 0.31$ & $1.27 \pm 0.34$ \\
\hline $\begin{array}{l}\text { LDL cholesterol } \\
(\mathrm{mmol} / \mathrm{l})\end{array}$ & $2.35 \pm 0.83$ & $2.53 \pm 0.88$ & $2.83 \pm 0.99$ \\
\hline
\end{tabular}

a)

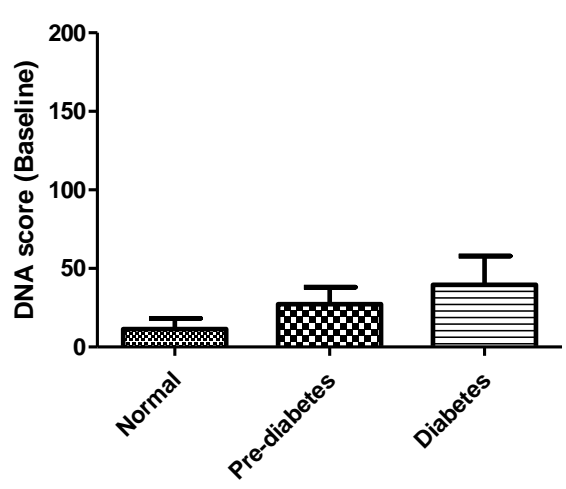

b)

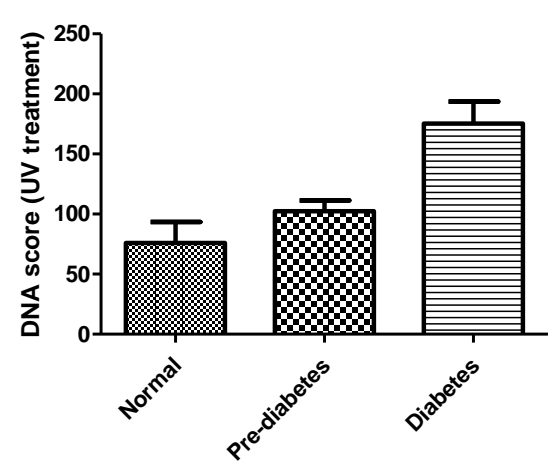

Fig. 1. DNA damage in healthy subject, pre-diabetic patients and diabetic patients. a) baseline DNA damage b) UV-induced DNA damage. Error bars represent $1 \mathrm{SD}$. The mean of each group is significantly different from each 
a)

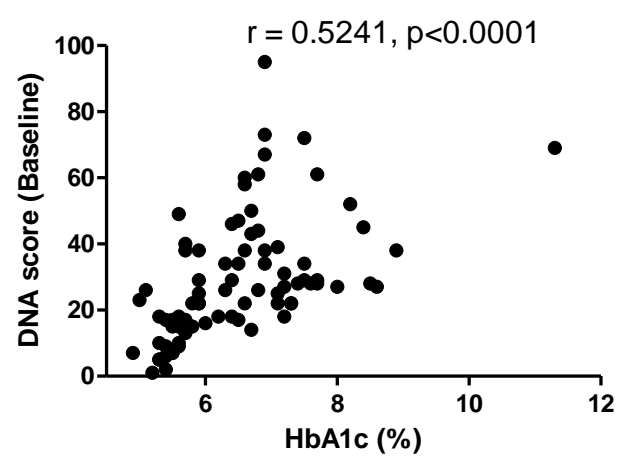

b)

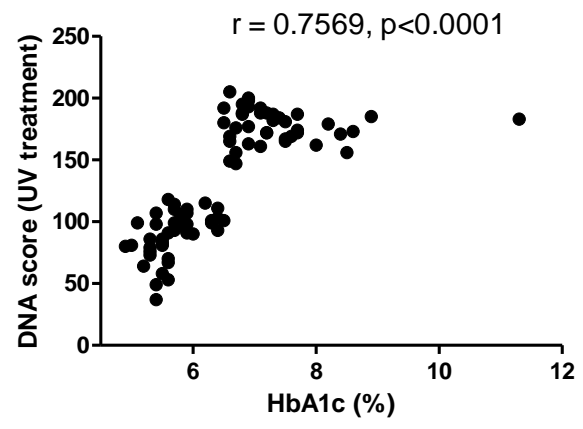

Fig. 2. Correlation between DNA score and $\mathrm{HbA}_{1 \mathrm{c}}$ level. a) baseline DNA damage b) UV-induced DNA damage. Pearson correlation, $p<0.001$ in both types of DNA damage.

Results showed that DM patients had highest DNA scores in both baseline and UV-induced damage. Where DNA damages of normal subjects were lowest. The baseline scores (mean $\pm \mathrm{SD}$ ) of normal subjects, pre-diabetic and diabetic were $11.4 \pm 6.9,27.2 \pm 10.8$ and $39.6 \pm 18.4$ respectively. While the UV-induced scores were $75.9 \pm 17.6,102.5 \pm 8.8$ and $175.4 \pm 18.2$, respectively. All groups showed statistically significant difference between each other $(\mathrm{p}<0.05)$. Strong positive correlation between $\mathrm{HbA}_{1 \mathrm{c}}$ level and DNA damage was seen and result are shown below: 2 a).

Baseline DNA damage vs $\mathrm{HbA}_{1 \mathrm{c}}, \mathrm{r}=0.5241, \mathrm{p}<0.001$ (Fig.

UV-induced DNA damage vs $\mathrm{HbA}_{1 \mathrm{c}}, \mathrm{r}=0.7569, \mathrm{p}<0.001$ (Fig. 2 b).

Baseline DNA damage vs fasting glucose, $r=0.5171$, $\mathrm{p}<0.001$.

UV-induced DNA damage vs fasting glucose, $r=0.7743$, $\mathrm{p}<0.001$.

\section{DISCUSSION}

In this study, the degree of DNA damage in patients with diabetes and the association between DNA damage and hyperglycemic state was investigated by comet assay, which is a simple and sensitive method to evaluate DNA integrity. Our findings agree with the hypothesis that diabetes mellitus associates with the DNA damage elevation in peripheral white blood cells. Diabetic and even pre-diabetic patients were under oxidative stress which evidenced by fragile DNA. Both categories of patient demonstrated higher basal and UVinduced DNA damage than healthy subjects (Fig. 1a). Strong positive correlation between $\mathrm{HbA}_{1 \mathrm{c}}$ level and comet score were seen in the study. Fasting glucose level demonstrated the same positive correlation pattern. The effects of high glucose condition to cell DNA integrity have been investigated but conflicting results reported [10], [11]. Both adverse effect or no effect on DNA from diabetic patients are suggested while our results demonstrated increased DNA damages in diabetes.

Previous study has shown that high blood sugar level takes an important role in the ROS formation by inducing mitochondrial stress and NADPH oxidation [12]. Glucose in circulation is converted to pyruvate through glycolysis. Pyruvate molecule is then transported to the mitochondria and generate $\mathrm{NADH}$ under the oxidization of tricarboxylic acid cycle. Normally, a small amount of incompletely reduced oxygen will escape from the respiratory chain constantly and form ROS as a natural byproduct of oxidative metabolism. Extra pyruvates formed in a high glucose state which results in the additional production of mitochondrial ROS. Hyperglycemia is also responsible for the production of advanced glycation end-products (AGEs) [13]. AGEs formed due to glycation of the amino group or amino acid residues of lipid or protein by reducing sugar. AGEs effect on both extracellular and intracellular function. When AGEs bind to the receptor for advanced glycation end-products on the basement membrane of cells, they activate the intracellular signaling cascade that promotes the activity of NADPH oxidase and hence the ROS generation [14]. Protein kinase B (Akt) pathway is another intracellular signaling pathway that would be activated in a high glucose concentration environment. Activation of Akt inhibit the function of tuberin and downregulate the DNA repair enzyme OGG1, thereby causing 8-oxodG accumulation. 8-oxodG is a byproduct of DNA oxidation. The accumulation of 8 -oxodG in cells is associated with genome instability and causing cancer and aging problem [15]. To maintain the genomic integrity, a series of DNA repair system is activated in response to oxidative stress-induced DNA damage. An in vitro renal epithelial cells study indicated that the DNA damage repair rate of cells was significantly lower in high glucose condition then low glucose condition [16].

The findings mentioned above suggest that diabetic patients have an elevated ROS production and increased degree of DNA lesions. The relationships between diabetes and increased risk of certain types of cancer are yet to determine but relieving patients from oxidative stress is worth to explore [17].

Current diabetes treatments mainly focus on weight loss, reduction of sugar intake and medication. Metformin is the first line medicine for diabetes treatment which reduce the glucose production from liver and increase the sensitivity of cell to insulin. Other than correcting blood glucose level, treatment to alleviate the oxidative stress of diabetes has been considered. The use of antioxidant may prohibit the reaction of ROS in body. Beneficial effects of antioxidant have been demonstrated in animal and human models. The antioxidant, $\mathrm{N}$-acetyl-L-cysteine (NAC), was prescribed to mice with type 2 diabetes and significant increase the size of beta cells was observed [18]. It might due to the relief of oxidative stress by antioxidant leading to suppression of beta cell apoptosis. Panax ginseng extract shows the ability to boost glucose 
metabolism and reduce blood glucose level in diabetic patients [19]. It is also an antioxidant which lowers human lymphocytic DNA damage [20]. Hence antioxidant supplement could be an additional consideration in diabetes treatment plan.

\section{CONCLUSION}

To conclude, our results showed higher DNA damage in diabetic and pre-diabetic patients and DNA damage in leucocytes was positively correlated with $\mathrm{HbA}_{1 \mathrm{c}}$ and fasting glucose levels. The use of antioxidant supplementation in line with standard diabetic treatment might be benefit to the patient and worth further investigation.

\section{ACKNOWLEDGMENT}

The authors would like to thank Chan \& Hou Medical Laboratories and Macao Society for the Study of Women's Health for the supporting of this study.

\section{REFERENCES}

[1] S. Simone, Y. Gorin, C. Velagapudi, H. E. Abboud and S. L. Habib, "Mechanism of oxidative DNA damage in diabetes: tuberin inactivation and downregulation of DNA repair enzyme 8-oxo-7,8dihydro-2'-deoxyguanosine-DNA glycosylase," Diabetes, vol. 57, pp. 2626-2636, 2008.

[2] C. Helou, D. Marier, P. Jacolot, L, Abdennebi-Najar, C. NiquetLéridon, F. J. Tessier FJ and P. Gadonna-Widehem, "Microorganisms and Maillard reaction products: a review of the literature and recent findings," Amino Acid. Vol. 46, pp. 267-277, 2014.

[3] A. Prasad, P. Bekker and S. Tsimikas, "Advanced glycation end products and diabetic cardiovascular disease," Cardiol. Rev., vol. 20, pp. 177-183, 2012.

[4] P. Saeedi, I. Petersohn, P. Salpea, D. Bright D and R. Williams, "Global and regional diabetes prevalence estimates for 2019 and projections for 2030 and 2045: Results from the International Diabetes Federation Diabetes Atlas, 9th edition", Diabetes Res. Clin. Pract., vol. 157, pp. 107843, 2019.

[5] T. Ohkuma, S. A. E. Peters, M. Woodward, "Sex differences in the association between diabetes and cancer: a systematic review and metaanalysis of 121 cohorts including 20 million individuals and one million events", Diabetol., vol. 61, pp. 2140-2154, 2018.

[6] J. Qi, P. He, H. Yao, R. Song, C. Ma, M. Cao, B. Cui and G. Ning, "Cancer risk among patients with type 2 diabetes: A real-world study in Shanghai, China”, J. Diabetes, vol. 11 pp. 878-883, 2019.

[7] J. P. Soares, A. Cortinhas, T. Bento, J. C. Leitão, A. R. Collins, I. Gaivão and M. P. Mota, "Aging and DNA damage in humans: a metaanalysis study", Aging, vol. 6, pp. 432-439, 2014.

[8] Y. T. Szeto, A. Lee, I. F. F. Benzie and H. Obied, "Optimized noninvasive procedures to measure DNA damage in comet assay" Human Exp. Toxicol., vol. 31, pp. 1144-1150, 2012.

[9] I. Hininger, A. Chollat-Namy, S. Sauvaigo, M. Osman, H. Faure, J. Cadet, A. Favier and A-M. Roussel, "Assessment of DNA damage by comet assay on frozen total blood: method and evaluation in smokers and non-smokers" Mutat. Res., vol. 558, pp. 75-80, 2004.

[10] J. Blasiak, M. Arabski, R. Krupa, K. Wozniak, M. Zadrozny, J. Kasznicki, M. Zurawska and J. Drzewoski, "DNA damage and repair in type 2 diabetes mellitus", Mutat. Res., vol. 554, pp. 297-304, 2004.

[11] A. Grindel, B. Guggenberger, L. Eichberger, C. Pöppelmeyer, M. Gschaider, A. Tosevska, G. Mare, D. Briskey, H. Brath and K-H. Wagner, "Oxidative stress, DNA damage and DNA repair in female patients with diabetes mellitus type 2", PloS One, vol. 11, pp. e0162082, 2016.

[12] P. V. Dludla, E. Joubert, C. J. F. Mulle, J. Louw and R. Johnson. (2017) Hyperglycemia-induced oxidative stress and heart diseasecardioprotective effects of rooibos flavonoids and phenylpyruvic acid2-O- $\beta$-D-glucoside", Nutr. Metabol. (Lond), 14:45 DOI 10.1186/s12986-017-0200-8.

[13] N. Schupp, R. Schinzel, A. Heidland and H. Stopper, "Genotoxicity of advanced glycation end products: involvement of oxidative stress and of angiotensin II type 1 receptors", Ann. N. Y. Acad. Sci., vol. 1043, pp. 685-695, 2015.

[14] M. P. Wautier, O, Chappey, S. Corda, D. M. Stern, A. M. Schmidt and J. L. Wautier, "Activation of NADPH oxidase by AGE links oxidant stress to altered gene expression via RAGE", Am. J. Physiol. Endocrinol. Metabol., vol. 280, pp. E685-E694, 2001.

[15] F. Gorini, G. Scala, G. D. Palo, G. I. Dellino, S. Cocozza, P. G. Pelicci, L. Lania, B. Majello and S. Amente, "The genomic landscape of 8oxodG reveals enrichment at specific inherently fragile promoters", Nucleic Acid Res., vol. 48, pp. 4309-4324, 2020.

[16] A. Zhong, M. Chang, T. Yu, R. Gau, D. J. Riley, Y. Chen and P. L. Chen. "Aberrant DNA damage response and DNA repair pathway in high glucose conditions", J. Cancer Res. Update, vol. 7, pp. 64-74, 2018.

[17] E. Giovannucci, D. M. Harlan, M. C. Archer, M. Bergenstal, S. M. Gapstur, L. A. Habel, M. Pollak, J. G. Regensteiner and D. Yee, "Diabetes and cancer: A consensus report", Diabetes Care, vol. 33, pp. 1674-1685, 2010.

[18] H. Kaneto, Y. Kajimoto, J. Miyagawa, T. Matsuoka, Y. Fujitani, Y. Umayahara, T. Umayahara, Y. Matsuzawa, Y. Yamasaki and M. Hori, "Beneficial effects of antioxidants in diabetes: possible protection of pancreatic beta-cells against glucose toxicity", Diabetes, vol. 48, pp 2398-2406, 1999.

[19] E. Shishtar, J. L. Sievenpiper, V. Djedovic, A. I. Cozma, V. Ha, V. H Jayalath, D. J. A. Jenkins, S. B. Meija, R. J. de Souza, E. Jovanovski, V. Vuksan, "The effect of ginseng (the genus panax) on glycemic control: a systematic review and meta-analysis of randomized controlled clinical trials", PloS One, vol. 9, pp. e107391, 2014.

[20] Y. T. Szeto, A. W. Ko, "Acute genoprotective effects on lymphocytic DNA with ginseng extract supplementation”, J. Aging Res. Clin. Pract., vol. 2, pp. 174-177, 2013. 